\title{
PRELIMINARY RESEARCH REGARDING THE CYTOTOXICITY AND ANTIOXIDANT ACTIVITY OF ARBUTUS UNEDO L. LEAVES
}

\author{
ADRIANA IULIANA ANGHEL ${ }^{1} *$, ROBERT ANCUCEANU ${ }^{1}$, MARIA LIDIA POPESCU ${ }^{2}$, \\ CERASELA ELENA GÂRD ${ }^{2}$, MIHAELA DINU ${ }^{1}$, MARILENA VIORICA HOVANEȚ ${ }^{1}$, IOANA \\ $\mathrm{NENCU}^{2}$ \\ 1 "Carol Davila" University of Medicine and Pharmacy, Faculty of Pharmacy, Pharmaceutical Botany and Cellular Biology \\ Department, 6 Traian Vuia Street, 020956, Bucharest, Romania \\ 2 "Carol Davila" University of Medicine and Pharmacy, Faculty of Pharmacy, Pharmacognosy, Phytochemistry and \\ Phytotherapy Department, 6 Traian Vuia Street, 020956, Bucharest, Romania
}

*corresponding author: anghel_adriana_iuliana@yahoo.com

Manuscript received: November 2020

\begin{abstract}
The aim of the study was the selection of optimum extraction procedure of Arbutus unedo L. leaves in order to obtain dry extracts with high content of polyphenols and arbutin. The antioxidant activity, cytotoxicity and genotoxicity of the extracts were also evaluated. Two types of extracts were obtained using refluxation and sonication, respectively. The total polyphenolic compounds were assessed spectrophotometrically with the Folin-Ciocâlteu method. Arbutin was detected and quantified by HPLC-DAD. The extracts' antioxidant activity was investigated using ferric reducing activity and 2,2diphenyl-1-picrylhydrazyl (DPPH) methods. The results were expressed as antioxidant activity index (AAI) for DPPH method and as EC50 $(\mu \mathrm{g} / \mathrm{mL})$ for both methods. Cytotoxicity/genotoxicity was verified by the Triticum (vegetal cell) and Artemia tests (animal cell). The highest content of arbutin, polyphenolic compounds and the highest DPPH free radical scavenging activity were found for the extract obtained by refluxation $(32.84 \mathrm{~g} \%$ polyphenols expressed as tannic acid, 1.92 $\mathrm{g} \%$ arbutin, $\mathrm{AAI}=6.45, \mathrm{EC} 50=43.78 \mathrm{mg} / \mathrm{mL}$ ). The extract containing the highest concentration in polyphenols is a very strong antioxidant as stated by antioxidant index. Despite the genotoxic effect of both extracts at high concentrations, low concentrations showed no cytotoxicity either on the plant cell or on the animal cell.
\end{abstract}

\section{Rezumat}

Scopul studiului a fost selectarea metodei optime de obținere a unor extracte uscate cu conținut ridicat de polifenoli și arbutozidă din frunzele de Arbutus unedo. Au fost evaluate activitatea antioxidantă, citotoxicitatea şi genotoxicitatea acestor extracte. Două extracte au fost obținute utilizând refluxarea și respectiv sonicarea. Totalul compușilor polifenolici a fost evaluat spectrofotometric prin metoda Folin-Ciocâlteu. Arbutina a fost detectată și cuantificată prin HPLC-DAD. Activitatea antioxidantă a fost investigată folosind două metode (DPPH și reducerea ferului). Rezultatele au fost exprimate prin intermediul EC50 $(\mu \mathrm{g} / \mathrm{mL})$ pentru ambele metode. Pentru metoda DPPH s-a calculat şi indicele de activitate antioxidantă (AAI). Citotoxicitatea/genotoxicitatea a fost verificată prin testele Triticum (celulă vegetală) și Artemia (celula animală). Cel mai mare conținut de arbutină, compuși polifenolici și cea mai mare activitate de eliminare a radicalilor liberi DPPH au fost găsite pentru extractul obținut prin refluxare $(32,84 \mathrm{~g} \%$ polifenoli exprimat ca acid tanic, $1,92 \mathrm{~g} \%$ arbutină, AAI = 6,45, EC50 $=43,78 \mathrm{mg} / \mathrm{mL}$ ). Extractul care conține cea mai mare concentrație în polifenoli este un antioxidant foarte puternic, după cum indică indicele antioxidant. În ciuda efectului genotoxic al ambelor extracte la concentrații mari, concentrațiile scăzute nu au prezentat citotoxicitate nici asupra celulei vegetale, nici asupra celulei animale.

Keywords: Arbutus, polyphenols, arbutin, antioxidant, cytotoxicity

\section{Introduction}

Arbutus unedo L. (strawberry tree) is a species of woody shrub type. It is widespread in the Mediterranean where it grows spontaneously and in many other parts of Europe as a cultivated plant. Currently it is a great interest for seeking micro-propagation species using adult plants in order to acclimation them $[11,12]$. The species is known mainly for decorative looks, given that flowers and fruits with different degrees of maturity coexist. The fruits are used for making alcoholic beverages, jams, marmalades or it is freshly consumed (in a lower manner) [35]. Traditional medicine recommended the leaves and fruit of the genus Arbutus as antiseptic, diuretic, laxative and antihypertensive remedy [24, 33].

The chemical composition of the whole plants or various organs was studied in order to exploit its therapeutic properties, because the species products have lower economic importance [22]. Fruits are the most studied organs of the plant. The chemical composition of the leaf is divers, previous studies showing the presence of the following active principles: flavones (quercitrin, isoquercitrin, hyperoside), phenol- 
carboxylic acids (chlorogenic acid), procyanidin dimers and other proanthocyanidins, tannins (catechins, gallocatechin, ethyl gallate), arbutin (only in leaves, up to $1.21 \mathrm{~g} \%$ ), sterols, triterpenes, essential oils, fatty acids, organic acids and vitamins [22, 27].

Previous investigations on the leaves of these species are modest, but pharmacological research has shown that Arbutus unedo extracts have antimicrobial (Candida albicans, Enteroccocus faecalis), antiparasitic (Trichomonas vaginalis) and antihypertensive properties [1, 9, 24]. The search for antimicrobial agents is an urgent need emerged from the increased antibiotic microbial resistance [38]. In this regard, new sources of substances with antimicrobial activity may be found in plants where compounds with different antimicrobial mechanism may coexist (inhibiting microbial growth, inducing cellular membrane perturbations, interfering with certain microbial metabolic processes, modulating signal transduction or gene expression pathways) [25].

Recent work shows that a high level of phenolic compounds depends on various and environmental or extraction factors $[3,4]$ and is correlated with antiinflammatory and antimicrobial activities [10]. In the case of Arbutus leaves, Malheiro et al. showed that the extracts with the highest antimicrobial activity are the richest in phenolic compounds [20]. Another phytochemical compound that can contribute to the antimicrobial activity of strawberry tree leaves is arbutin and its' metabolite hydroquinone [16]. Therefore, in order to obtain standardized extracts with antimicrobial activity, we have focused on the content of phenolic compounds and arbutin.

Currently, the best source of arbutin is Arctostaphylos uva-ursi, but the plant is protected by law in Romania, being considered a natural monument. Hydroquinone (the active part of the arbutin) may have genotoxic and carcinogenic effects [21], although it was estimated that at the usual doses of arbutin commonly used by humans it is unlikely to be unsafe [6]; in this context we considered useful to evaluate the cytotoxic/genotoxic potential of the extracts.

\section{Materials and Methods}

\section{Chemicals and Materials}

All solvents and reagents were purchased from Carl Roth (Germany) and Sigma-Aldrich (Germany).

Arbutin, DPPH and ABTS were purchased from Carl Roth (Germany).

Plant material

The leaves of Arbutus unedo were collected in mainland Greece (Nikea) during September 2018 and October 2018. A voucher specimen (no. 230) was deposited at the Herbarium of the Department of Pharmacognosy, Faculty of Pharmacy, "Carol Davila" University of Medicine and Pharmacy, Bucharest, Romania. The herbal products were naturally dried in shade and stored in controlled laboratory conditions.
Sample preparation

Microscopic determination. For the microscopic analysis, $\mathrm{NaOH}(5 \% \mathrm{w} / \mathrm{v})$, carmine alum, green iodine and acetic orcein (for phytobiological testing) were used. Microscopic preparations were obtained from fresh biological material (leaves) by cross sectioning; superficial preparations were also analysed. Micrographs were obtained with a Nikon microscope Labophot 2.

Spectrophotometric and chromatographic determination. Two extraction procedures were used: refluxation (heating at $60^{\circ} \mathrm{C}$ using a reflux condenser and a water bath) and ultrasonication at room temperature (with an Elmasonic S15H ultrasonic bath). For both procedures, $5 \mathrm{~g}$ of powdered leaves were heated/ultrasonicated for 30 minutes, with $100 \mathrm{~mL}$ of hydroalcoholic mixture (water:ethanol $=50: 50 \mathrm{v} / \mathrm{v}$ ). After cooling and cotton filtration, the solutions were filled up to $100 \mathrm{~mL}$ with solvent in a volumetric flask. The extractive solutions were codified as AU1 (obtained by heating) and AU2 (obtained by ultrasonication).

In vitro genotoxicity and cytotoxicity analysis. The genotoxic/cytotoxic potential was tested in vitro on Triticum aestivum $\mathrm{L}$. seeds coming from organic crops (Râmnicu Sărat, Buzău, Romania) and on Artemia salina from Grate Salt Lake (USA). For the in vitro genotoxicity and cytotoxicity analysis, the solutions were brought to dry residue in a water bath and the residue was suspended in distilled water.

Analytical Methods

Total phenolics content assay

Determination of the total phenolic (TP) compounds. Determination of the total phenolic compounds, expressed as tannic acid equivalents, was performed according to Folin-Ciocâlteu method [17]. The blue complex (obtained from the oxidation of polyphenols via Folin-Ciocâlteu reagent) is assessed by absorbance at $725 \mathrm{~nm}$, against a reference solution of tannic acid. The results are expressed as tannic equivalents/100 g dry extract, using a standard curve, linear between $2.1-12.12 \mu \mathrm{g} / \mathrm{mL}\left(\mathrm{Y}=0.0605 \mathrm{X}+0.0533, \mathrm{r}^{2}=0.999\right.$, where $\mathrm{Y}=$ absorbance, and $\mathrm{X}=$ concentration).

Determination of the antioxidant activity using DPPH assay. (1,1-diphenyl-2-picrylhydrazil) was employed according to Brand-Williams (1995) with slight modifications [19]. The reaction is based on the reduction of purple radical DPPH (1,1-diphenyl-2picrylhydrazil) to yellow 1,1-diphenyl-2-picrylhydrazine. Briefly, $2 \mathrm{~mL}$ of $120 \mu \mathrm{M}$ DPPH was added to $2 \mathrm{~mL}$ of the extract solution at different concentrations (0.020 - $217 \mathrm{mg}$ of extracts). The flasks were shaken energetically and kept in the dark, at room temperature for 30 minutes. The absorbance was measured against blank (absolute ethanol) at the maximum absorbance of DPPH $(\lambda=516 \mathrm{~nm})$ using a spectrophotometer Jasco V-530, Germany. The assays were carried out in triplicate and the results were expressed as $\mathrm{mg} / \mathrm{mL}$ extract that inhibits with $50 \%$ the DPPH absorbance 
FARMACIA, 2021, Vol. 69, 2

(EC50). The factor was calculated graphically from the linear regression curve plotted between radical inhibition (\%) and dry extracts concentrations $(\mathrm{mg} / \mathrm{mL})$. The extracts' antioxidant activity was compared to gallic acid EC50 factor, performed in similar conditions. In order to compare the antioxidant potency of the extracts with other scientific results, the antioxidant activity was represented also as an antioxidant index [32], calculated from the following relation:

$\mathrm{AAI}=$ final concentration of DPPH $(\mathrm{mg} / \mathrm{mL}) / \mathrm{EC} 50$ $(\mathrm{mg} / \mathrm{mL})$ [32].

Polyphenols are major contributors to the antioxidant activity of plants [23]. Therefore, we considered that a correlation between DPPH inhibition and the polyphenols content of the extracts is welcomed.

Reducing power assay. The reducing power assay was determined according to Oyaizu, with slight modification by Jayanthi [15]. Antioxidant compounds reduce potassium ferricyanide $\left(\mathrm{Fe}^{3+}\right)$ to ferrocyanide $\left(\mathrm{Fe}^{2}+\right)$, which reacts with ferric chloride to form ferric ferrous complex. The ferric ferrous complex absorbance is directly proportional with the extract reducing power. Briefly, $2.5 \mathrm{~mL}$ of extract solutions were mixed with phosphate buffer $\mathrm{pH} 6.6(2.5 \mathrm{~mL})$ and potassium ferricyanide $(2.5 \mathrm{~mL})$. The mixture was kept at $50^{\circ} \mathrm{C}$ for 20 minutes. After cooling, $2.5 \mathrm{~mL}$ of $10 \%$ trichloroacetic acid was added, and the mixture was centrifuged at $3000 \mathrm{rpm}$ for 10 minutes. The upper layer was mixed with $2.5 \mathrm{~mL}$ fresh distilled water and $0.5 \mathrm{~mL}$ of $1 \%$ ferric chloride. The absorbance was measured against controls (prepared with the same ingredients and procedure, except the extracts) at the $700 \mathrm{~nm}$ wavelength. The assays were carried out in triplicate and the results are expressed as mean values \pm standard deviations.

The antioxidant activity was also expressed as EC50 $(\mathrm{mg} / \mathrm{mL})$ that represents the analysed dry extract concentration providing 0.5 of absorbance. It was determined graphically from the linear regression curve plotted between absorbance and test solutions concentrations $(\mathrm{mg} / \mathrm{mL})$.

The TP influence on the reducing power of the extracts was established using a correlation between the blue complex absorbance and their polyphenolic content. HPLC analysis

In order to identify and quantify the content of arbutin a HPLC-DAD method was used, on a Jasco HPLC MD-2015 equipped with degasser, binary gradient pump, column thermostat and UV detector. The HPLC method was the one provided by the European Pharmacopoeia for Echinaceae angustifolia radix. The experimental conditions were the following: RP Nucleosil - C18 25 x 0.4 mm i.d, $5 \mu$ m column; the mobile phase: acetonitrile and phosphoric acid $0.1 \%$ (v/v); the elution started at $90 \%$ to $78 \%$ phosphoric acid $0.1 \%$ for 13 minute, then decreased from $78 \%$ to $60 \%$ in 1 minute, followed by an isocratic flow with $60 \%$ phosphoric acid $0.1 \%$ for another $6 \mathrm{~min}$; system flow rate: $1.5 \mathrm{~mL} / \mathrm{min}$; injection volume: 20 $\mu \mathrm{L}$; detection: $218 \mathrm{~nm}$. The chromatographic data were processed using the Chrompass software from Jasco, Japan. The retention time of the arbutin (370 $\mu \mathrm{g} / \mathrm{mL}$ ) was obtained from 5 consecutive injections of the reference solution.

Phytobiological analysis

The effect of the extractive solutions AU1 and AU2 was determined using the Triticum Bioassay (method of Constantinescu) [7]. The method is based on determining the highest dilution of active substance influencing the elongation of the root and the caryokinetic film, depending on the duration of action. Five concentrations of each extractive solution (3.33, $2.50,1.67,0.33$ and $0.03 \%$ ) were tested and distilled water was used as a negative control. An index of inhibition was also calculated based on median values. The comparison of root length was performed 72 hours from baseline. EC50 was determined by nonlinear regression modelling of the Efi versus $\log \mathrm{C}$ (concentration of the tested extract solution).

Artemia franciscana nauplii toxicity

The acute toxicity of the different samples can be verified using Artemia organisms [14]. The brine shrimp lethality test used is briefly described. Artificial sea water was prepared by dissolving a commercial salt mixture (CoralMarine, Grotech) in distilled water (33.4 g/L). Artemia franciscana (Kellogg, 1906) cysts, derived from Grate Salt Lake (USA) were purchased from Ocean Star International (USA), repackaged by S.K. Trading (Thailand). Hatching was initiated roughly 48 hours before the test initiation, by immersing about 2 grams of cysts in $500 \mathrm{~mL}$ artificial marine water at $25^{\circ} \mathrm{C}$, under continuous aeration. The hatched organisms (nauplii) were used within a 10 hour interval from hatching. The nauplii were separated from cyst remainders and concentrated by placing them in a $100 \mathrm{~mL}$ crystallizing dish and using a light source positioned towards its bottom. From the crystallizing dish nauplii were transferred with a Pasteur pipette in a smaller crystallizing dish $(10 \mathrm{~mL})$, from which they were collected for testing.

Statistical analysis

Origin 6.1 is the statistical software used to calculate the average, standard deviation $\left( \pm \mathrm{sx}_{\mathrm{m}}\right)$ and the determination factors $\left(\mathrm{r}^{2}\right)$ for mathematical correlations (P.T. with DPPH/Reducing power assay). The results of the genotoxicity and cytotoxicity tests were interpreted statistically using the Kruskal-Wallis test, because after checking their distribution by the D'Agostino \& Pearson and Shapiro-Wilk tests an abnormal distribution has been observed. The Dunn's post-hoc test was used for multiple comparisons between different concentrations and the control group. GraphPad Prism 5 was used to calculate the EC50 and for statistical interpretation. 


\section{Results and Discussion}

The macroscopic characters and the microscopic analysis confirmed the identity of the species Arbutus unedo L. in agreement with the literature data [12]. The following anatomical features were observed: glandular hairs on the young leaves; mature leaf with spiny edge; dorsiventral structure with a double palisade layer; partially sclerenchymatous pericycle (in the median rib). The anomocytic stomata, prismatic calcium oxalate crystals and drops of oil were observed in the superficial preparations.

The chromatographic and spectrophotometric results are found in Table I. The arbutin calibration curve in the $0.5-5.0 \mathrm{mg} / \mathrm{mL}$ range had good linearity $\left(\mathrm{r}^{2}=\right.$ $0.994, \mathrm{n}=5$ ). The polyphenolic and arbutin content is higher for AU1 than for AU2 (Table I). Thus, the arbutin content of the extracts increases with the temperature of extraction. Positive influence of an increased temperature maintained for short time on arbutin extraction was also reported for other herbal products [29, 32]. Similar statement may be made for poyphenolic compounds as well [37]. The ultrasonic process can increase mass transfer between raw material and solvent [31], but in our case, the influence of high temperature, is more effective for the extraction of TP. Our results (32.84 and $10.44 \mathrm{~g} \%$ tannic acid, for refluxation and sonication extracts, respectively) are higher than ones found by Parissi et al. $(1.9 \mathrm{~g} \%$ tannic acid) [26], but other comparisons with scientific reports are difficult because most scientific papers express TP content of Arbutus unedo leaves as gallic acid equivalents [13].

\begin{tabular}{|c|c|c|c|c|c|c|c|}
\hline \multirow[t]{2}{*}{ Sample } & \multirow{2}{*}{$\begin{array}{c}\text { g\% total polyphenolic compounds } \\
\text { expressed as tannic acid }\end{array}$} & \multicolumn{3}{|c|}{ DPPH } & \multirow{2}{*}{\multicolumn{2}{|c|}{$\begin{array}{c}\text { Reducing power assay } \\
\text { (EC50) }\end{array}$}} & \multirow{2}{*}{$\begin{array}{l}\mathrm{g} \% \\
\text { arbutin }\end{array}$} \\
\hline & & \multicolumn{2}{|c|}{ EC50 $(\mathrm{mg} / \mathrm{mL})$} & AAI & & & \\
\hline AU 1 & $32.84 \pm 2.45$ & $3.72 \pm 0.36$ & \multirow[t]{2}{*}{$\mathrm{p}<0.05$} & 6.45 & $57.41 \pm 0.56$ & \multirow[t]{2}{*}{$\mathrm{p}<0.05$} & 1.92 \\
\hline AU 2 & $10.44 \pm 3.61$ & $22.28 \pm 0.28$ & & 1.05 & $43.78 \pm 1.09$ & & 0.52 \\
\hline Gallic acid & - & $15.51 \pm 0.32$ & - & 1.54 & $88.6 \pm 0.02$ & - & - \\
\hline
\end{tabular}

The DPPH technique is often used to evaluate the antioxidant properties of plant extracts. The EC50 values are inversely correlated with the antioxidant activity of the extracts (Table I). The antiradicalar activity decrease in the following order: AU1 > Gallic acid > AU2. The fact that an extract (AU1) may have a higher activity than the standard has also been reported by other authors. Djabou et al. found that an ethyl acetic extract of Arbutus sp. exhibits a higher reduction of the free radicals than ascorbic acid and catechin [8].

Another way to express the antioxidant activity of the extracts is by means of AAI (antioxidant activity index). Due to the fact that the EC50 values depend on the initial free radical concentration, the AAI was used to classify the antioxidant activity of the extracts [32]. According to Scherer R et al., the antioxidants are divided in: weak (AAI $<0.5$ ), moderate (AAI < 0.5 - 1.0), strong (AAI < $1.0-2.0$ ) and very strong (AAI > 2.0) [32]. As such, AU1 is a very strong antioxidant and AU2 and gallic acid are strong antioxidants.

The ferric reducing assay evaluate the ability of compounds to act as antioxidants in the system, by reducing the $\mathrm{Fe}^{3+}$ to its more active $\mathrm{Fe}^{2+}[29,30]$. As such, the antioxidant capacity is evaluated by the formation of $\mathrm{Fe}^{2+}$ in the Perl's Prussian complex, whose absorbance is assessed at $700 \mathrm{~nm}$ [29]. The antiradicalar activity expressed as EC50 is found in Table I. In this case, AU2 has a higher antioxidant activity than AU1, in an opposite manner to the results obtained in the DPPH method. A possible explanation resides in the chemical composition of the extracts.
As, by ultrasonication, thermolabile compounds (like ascorbic acid) are protected, they may reinforce the polyphenol activity to give higher reduction of the ferric salts. Therefore, the antioxidant activity of the extract depends not only on polyphenols, but also on other compounds. Another possible explanation is related to the fact that low temperature extraction procedures might give lower quantities of polyphenols, but with higher antiradicalar activity than heating procedure methods [5].

As it was expected, for DPPH method the determination factor $\mathrm{r}^{2}$ between the EC50 and the polyphenolic content has a high value $\left(r^{2}=0.932\right)$, which indicate that phenolic compounds are responsible for the antioxidant activity. Another influence might be due to the higher content of arbutin obtained by refluxation. For the ferric reducing assay, the $\mathrm{r}^{2}$ factor has lower value indicating that other compounds are involved in the antiradicalar activity of the extracts.

Phytobiological analysis

By analysing data from the third day obtained from by calculating of inhibition indices for both extractive solutions, it was found that, as expected, at high concentrations $(3.33-1.66 \%)$, the inhibitory effect is strong (greater than $95 \%$ for both solutions $-\mathrm{p}<0.001$ ). For the concentration of $0.33 \%$, the two extracts also showed a high, statistically significant inhibitory effect, (greater than $85 \%$ for both solutions $-\mathrm{p}<0.001$ ). For the lowest of the tested concentrations $(0.03 \%)$ the inhibitory effect $(41.89 \%$ for AU1 and $21.49 \%$ for AU2), it was proved to be statistically insignificant $(\mathrm{p}>0.05)$. For the solution produced by sonication (AU2), the determined inhibitory effect has half of 
the value of the one determined for the solution obtained by refluxing at the lowest concentrations (Figures 1, 2 and 3 ). In addition, EC50 for AU2 and for AU1 is presented in Table II.

Table II

EC50 of the root growth

\begin{tabular}{|l|c|c|}
\hline \multicolumn{1}{|c|}{ Parameters } & $\begin{array}{c}\text { AU 1 } \\
(\mathbf{m g} / \mathbf{1 0 0} \mathbf{~ m L})\end{array}$ & $\begin{array}{c}\text { AU 2 } \\
(\mathbf{m g} / \mathbf{1 0 0} \mathbf{~ m L})\end{array}$ \\
\hline EC50 & 41.89 & 82.93 \\
\hline Standard error of EC50 & 0.15 & 0.09 \\
\hline $\begin{array}{l}\text { Confidence interval for } \\
\text { EC50 }(\alpha=0.05)\end{array}$ & $3.27-4.20$ & $4.12-4.72$ \\
\hline Goodness of Fit $\left(\mathrm{r}^{2}\right)$ & 0.9786 & 0.9956 \\
\hline
\end{tabular}

Day 1 AU1
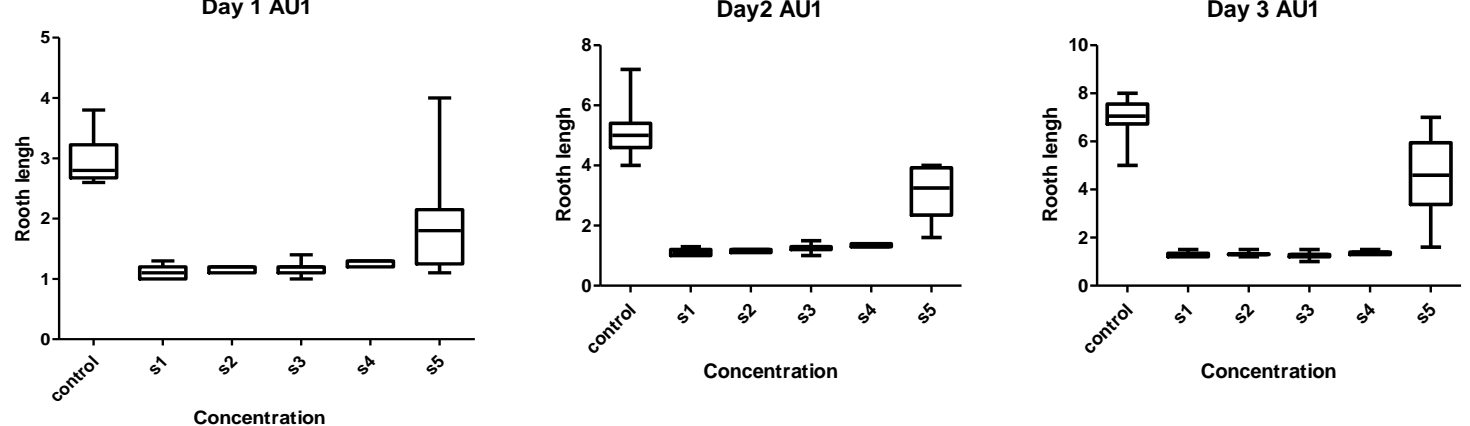

Figure 2.

Boxplot representation of the effects of the AU1 on Triticum main root growth over 3 days s1 - s5 = samples with different concentrations

Day 1 AU2

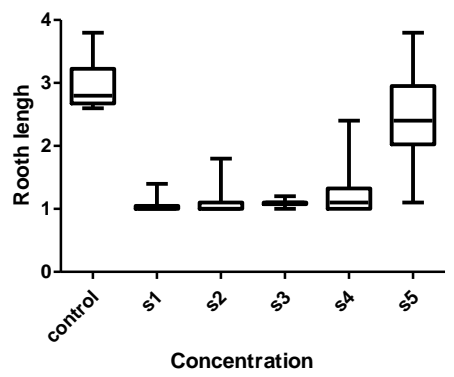

Day2 AU2

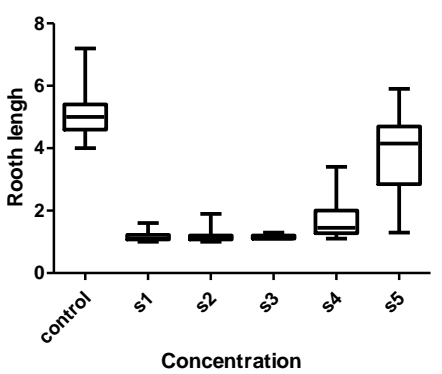

Day3 AU2

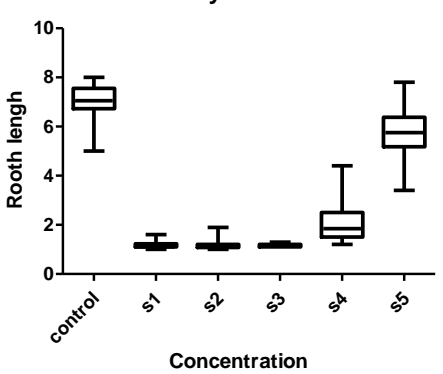

Figure 3.

Boxplot representation of the effects of the AU2 on Triticum main root growth over 3 days s1 - s5 = samples with different concentrations

The microscopic examination of the preparations has shown mitoinhibitory effects (Figure 4), micronuclei (Figure 5) and disorganization of nuclear material (Figure 7) the $3.3-0.3 \%$ concentration interval, and changes in the mitotic film like tropokynesis at the lowest concentration $(0.03 \%)$ (Figure 6). Cytotoxicity and genotoxicity seen in the presence of high concentrations might be caused by the polyphenols and arbutin [36].

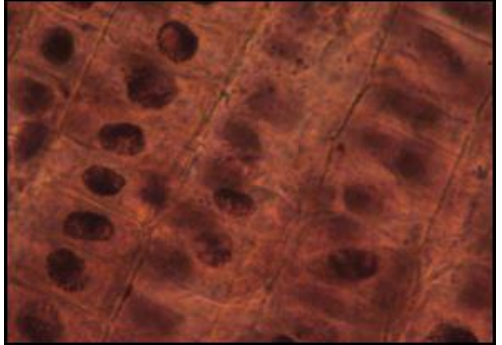

Figure 4.

Mitoinhibition (ob. 100x) 


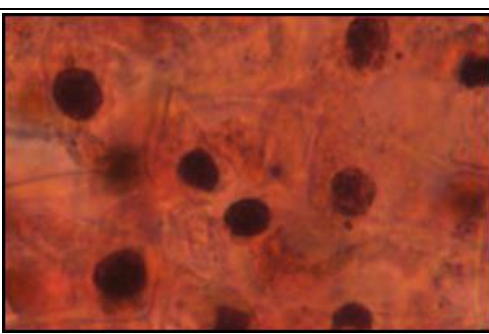

Figure 5.

Micronuclei (ob. 100x)

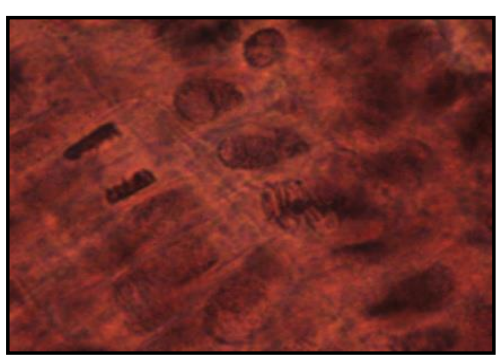

Figure 6.

Telophase, metaphase in tropokinesis, interphases

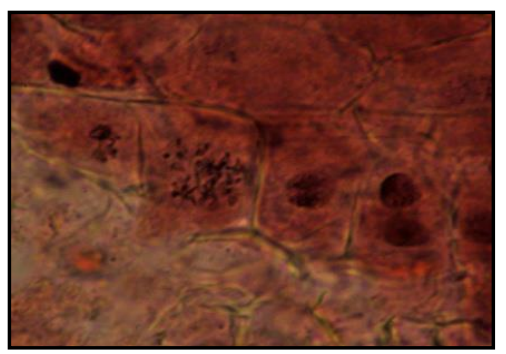

Figure 7.

Disorganization of nuclear material

\section{Artemia test}

Because the extractive solution AU1 showed the highest cytotoxic effect by the phytobiological method, cytotoxicity was also tested by the Artemia method at $1.8 \mathrm{mg} / \mathrm{mL}, 9 \mathrm{mg} / \mathrm{mL}, 4.5 \mathrm{mg} / \mathrm{mL}, 2.25 \mathrm{mg} / \mathrm{mL}$ and $1.125 \mathrm{mg} / \mathrm{mL}$ concentrations. At the highest concentration tested, the lethality was $100 \%$, while for all other levels it was, $0 \%$. This indicates a very low level of toxicity, although at extremely high concentrations the lethality-concentration curve is very steep. In the literature on Artemia lethality test, I50 levels higher of $500 \mu \mathrm{g} / \mathrm{mL}$ or higher have been described as "practically non-toxic". As the LC50 for the AU1 extract is higher than $9000 \mu \mathrm{g} / \mathrm{mL}$, it may be considered virtually nontoxic. The difference in effects between plant animal cells may be related to the different sensitivity of plant cells to other compounds, such as tannins (known to inhibit seed germination and plant growth), which are very likely present in the extracts [30]. Kivcak et al., in 2009, checked the in vitro action of Arbutus leaves using several solvents. In their research, they considered the previous results of the cytotoxicity tests of the extracts obtained with n-hexane, ethyl acetate and water on Artemia salina (crustacean). The extracts with hexane and water were found to be toxic and the ethanol and ethyl acetate did not show toxicity by the Artemia method [18].

\section{Conclusions}

The hydroethanolic extract obtained by refluxation has the highest content of arbutin, polyphenolic compounds and is classified as a very strong antioxidant, according to the antioxidant activity index. The antioxidant activity depends on the chemical composition of the extracts that varies with the extraction procedure. The ferric reducing activity is higher for the extract obtained by ultrasonication. Both analysed extracts showed induced genotoxic effects on plant cells at high concentrations. Low concentrations showed no toxicity on Artemia franciscana (for AU1, LC50 higher than $9000 \mu \mathrm{g} / \mathrm{mL}$ ), indicating that the extract may be considered "practically non-toxic".

\section{Conflict of interest}

The authors declare no conflict of interest.

\section{References}

1. Afkir S, Nguelefack TB, Aziz N, Zoheir J, Cuisinaud G, Bnouham M, Mekhfi H, Legssyer A, Lahlou S, Ziyyat A, Arbutus unedo prevents cardiovascular and morphological alterations in L-NAME-induced hypertensive rats Part I: cardiovascular and renal hemodynamic effects of Arbutus unedo in L-NAMEinduced hypertensive rats. J Ethnopharmacol., 2008; 116(2): 288-295.

2. Al Hilfi Zaid Abdulridha Flayyh, Nencu I, Costea T, Gîrd CE, Stoicescu CS, Anghel AI, Ancuceanu RV, Dinu M, Ionică FE, Seremet OC, Negreş S, Chemical composition and antioxidant activity of Ficus elastica Roxb. Ex Hornem and Raphanus sativus L. selective dry extracts with potential antidiabetic activity. Farmacia, 2019; 67(5): 764-771.

3. Ancuceanu R, Anghel AI, Hovaneț MV, Dinu M, Olaru OT, Dune A, Ciolea M, Stoicescu CS, Popescu C, Variation of iron contents, polyphenols and flavonoids in Petroselinum crispum (Mill.) Fuss (Apiaceae). Farmacia, 2018; 66(2): 275-281.

4. Anghel AI, Olaru OT, Gatea F, Dinu M, Ancuceanu $\mathrm{RV}$, Istudor V, Preliminary research on Portulaca grandiflora Hook. species (Portulacaceae) for therapeutic use. Farmacia, 2013; 61(4): 694-702.

5. Chew KK, Ng SZ, Thoo ZZ, Khoo MY, Wan A, Ho CW, Effect of ethanol concentration, extraction time and extraction temperature on the recover of phenolic compounds and antioxidant capacity of Centella asiatica extracts. Int Food Res J., 2011; 18: 571-578.

6. De Arriba SG, Naser B, Nolte KU, Risk assessment of free hydroquinone derived from Arctostaphylos Uva-ursi folium herbal preparations. Int J Toxicol., 2013; 32(6): 442-453.

7. Dinu M, Anghel AI, Olaru TO, Seremet OC, Calalb T, Cojocaru-Toma M, Negres S, Hovanet MV, Zbarcea $\mathrm{CE}$, Ancuceanu R, Toxicity investigation of an extract of Amaranthus retroflexus L. (Amaranthaceae) leaves. Farmacia, 2017; 65(2): 289-229. 
FARMACIA, 2021, Vol. 69, 2

8. Djabou N, El Amine M, Allali H, Evaluation of antioxidant and antimicrobial activities of the phenolic composition of Algerian Arbutus unedo L. roots. Pharmacogn J., 2013; 5(6): 275-280.

9. Ertabaklar H, Kivcak B, Mert T, Ozensoy Toz S, In vitro Activity of Arbutus unedo Leaf Extracts against Trichomonas vaginalis Trophozoites. Turkiye Parazitoloji Derg., 2009; 33(4): 263-265.

10. Fattouch S, Caboni P, Coroneo V, Tuberoso CIV, Angioni A, Dessi S, Marzouki N, Antimicrobial Activity of Tunisian Quince (Cydonia oblonga Miller) Pulp and Peel Polyphenolic Extracts. J Agric Food Chem., 2007; 55(3): 963-969.

11. Gomes F, Canhoto MJ, Micropropagation of strawberry tree (Arbutus unedo L. from adult plants). In Vitro Cell Dev Biol Plant, 2009; 45: 72-82.

12. Gomes MFFN, PhD Thesis - Universidade de Coimbra; Coimbra, Portugal: Strategies for the Improvement of Arbutus unedo L. (Strawberry Tree): In vitro Propagation, Mycorrhization and Diversity Analysis, 2011; 68-70, https://core.ac.uk/download/pdf/19131968.pdf

13. Guendouze-Bouchefa N, Madfani K, Chibane M, Boulekbache-Makhlouf L, Hauchard D, Kiendrebeogo M, Stevigni C, Okusa PN, Duez P, Phenolic compounds, antioxidant and antibacterial activities of three Ericaceae from Algeria. Ind Crops Prod., 2015; 70: 459-466.

14. Hamidi MR, Jovanova B, Kadifkova-Panovska T, Toxicological evaluation of the plant products using Brine Shrimp (Artemia salina L.) model. Maced Pharm Bull., 2014; 60(1): 9-18.

15. Jayanthi $\mathrm{P}$, Lalitha $\mathrm{P}$, Reducing power of the solvent extract of Eichhornia crassipes (mart.) Solms. Int J Pharm Pharm Sci., 2011; 3(3): 126-128.

16. Jurica K, Gobin I, Kremer D, Vitali CD, Jurisic Grubesic R, Brcic Karaconji I, Kosalec I, Arbutin and its metabolite hydroquinone as the main factors in the antimicrobial effect of strawberry tree (Arbutus unedo L.) leaves. J Herb Med., 2017; 8(C): 17-23.

17. Katoch R, Analytical techniques in biochemistry and molecular biology, Springer, 2011; 357.

18. Kivcak B, Mert T, Ertabaklar H, Balcioglu IC, Ozensoy Toz S, In vitro activity of Arbutus unedo against Leishmania tropica promastigotes. Turkiye Parazitol Derg., 2009; 33(2): 114-115.

19. Kukric Z, Topalic-Trivunovica L, Kukavicab B, Matosa SB, Pavicica SS, Borojab MM, Characterization of antioxidant and antimicrobial activities of nettle leaves (Urtica dioica L.). APTEFF, 2012; 43: 257-272.

20. Malheiro R, Olga SA, Pereira E, Aguiar CA, Baptista P, Pereira JA, Arbutus unedo L. leaves as source of phytochemicals with bioactive properties. Ind Crops Prod., 2012; 37(1): 473-478.

21. McGregor D, Hydroquinone: An Evaluation of the Human Risks from its Carcinogenic and Mutagenic Properties. Crit Rev Toxicol., 2007; 37(10): 887-914.

22. Miguel MG, Faleiro MF, Guerreiro AC, Antunes MD, Arbutus unedo L.: Chemical and Biological. Properties. Molecules, 2014; 19(10): 15799-15823.

23. Mihai S, Dumitrescu D, Raducanu MA, Stoicescu I, Badea V, Phytochemical Profile and Total Antioxidant Capacity of Sempervivum ruthenicum Koch Hydroethanolic Extract. Rev Chim., 2019; 70(1): 23-26.
24. Oliveira I, Baptista P, Bento A, Pereira JA, Arbutus unedo L. and its benefits on human health. J Food Nutr Res., 2011; 50(2): 73-85.

25. Omojate GC, Enwa FO, Jewo AO, Eze CO, Mechanisms of antimicrobial actions of phytochemicals against enteric pathogens - a review. J Pharm Chem Biol Sci., 2014; 2(2): 77-85.

26. Parissi ZM, Abraham ME, Roukos C, Kyriazopoulos AP, Petridis A, Karameri E, Seasonal Quality Assessment of Leaves and Stems of Fodder Ligneous Species. Not Bot Horti Agrobot Cluj Napoca, 2018; 46(2): 426-435.

27. Pavlovic DR, Brankovic S, Kovacevic N, Kitic D, Veljkovic S, Comparative study of spasmolytic properties, antioxidant activity and phenolic content of Arbutus unedo from Montenegro and Greece. Phytother Res., 2011; 25(5): 749-754.

28. Pereira JA, Pereira APG, Ferreira ICFR, Valentao P, Andrade PB, Seabra R, Estevinho L, Bento A, Table olives from Portugal: phenolic compounds, antioxidant potential and antimicrobial activity. J Agric Food Chem., 2006; 54(22): 8425-8431.

29. Pop C, Vlase L, Tamas M, Natural resources containing arbutin. Determination of arbutin in the leaves of Bergenia crassifolia (L.) Fritsch. acclimated in Romania. Not Bot Hort Agrobot Cluj Napoca, 2009; 37(1): 129-132.

30. Rao VS, Principles of Weed Science, Second Edition. Science Publishers, Enfield (NH), 2000; 332.

31. Rodrigues S, Pinto GAS, Fernandes FAN, Optimization of ultrasound extraction of phenolic compounds from coconut (Cocod nucifera) shell powder by response surface methodology. Ultrason Sonochem., 2008; 15(1): 95-100.

32. Scherer R, Godoy H, Antioxidant activity index (AAI) by the 2,2-diphenyl-1-picrylhydrazyl method. Food Chem., 2009; 122(3): 654-659.

33. Seker M, Toplu C, Determination and Comparison of Chemical Characteristics of Arbutus unedo L. and Arbutus andrachnae L. (Family Ericaceae) Fruits. J Med Food, 2010; 13(4): 1013-1018.

34. Sheng ZW, Ma WH, Gao JH, Bi Y, Zhang WM, Dou HT, Jin ZQ, Antioxidant properties of banana flower of two cultivars in China using 2, 2-diphenyl-1picrylhydrazyl (DPPH,) reducing power, 2, 2'-azinobis-(3ethylbenzthiazoline-6-sulphonate (ABTS) and inhibition of lipid peroxidation assays. Afr J Biotechnol., 2011; 10(21): 4470-4477.

35. Soufleros EH, Mygdalia SA, Natskoulis P, Production process and characterization of the traditional Greek fruit distillate "koumaro" by aromatic and mineral composition. J Food Compos Anal., 2005; 18(7): 699-716.

36. Taner G, Aydin S, Aytac Z, Basaran AA, Basaran N, Assessment of the cytotoxic, genotoxic, and antigenotoxic potential of Pycnogenol ${ }^{\circledR}$ in in vitro mammalian cells. Food Chem Toxicol., 2013; 61: 203-208.

37. Wan C, Yu Y, Zhou S, Liu W, Tian S, Cao S, Antioxidant activity of free radical-scavenging capacity of Gynura divaricata leaf extracts at different temperatures. Pharmacogn Mag., 2011; 7(25): 40-45.

38. Word Health Organization, Antimicrobial resistance, 2015, no. 194, www.who.int/mediacentre/factsheets. 